\section{Effects of planting density on the distribution of biomass in a douglas-fir plantation in southern Italy}

\author{
Pasquale A Marziliano ${ }^{(1)}$, Vittoria Coletta ${ }^{(2)}$, Giuliano Menguzzato ${ }^{(1)}$, \\ Antonino Nicolaci ${ }^{(3)}$, Gaetano Pellicone ${ }^{(2)}$, Antonella Veltri ${ }^{(2)}$
}

The effects of initial planting densities on the distribution of above-ground biomass of Douglas-fir (Pseudotsuga menziesii [Mirb.] Franco var. menziesii) were investigated in a plantation in southern Italy. Allometric equations designed for the plantation under study were used to estimate above-ground biomass and its partitioning to stem and crown compartments. A comparison between biomass estimated with allometric equations and biomass estimated with a constant biomass expansion factor (BEF) from the Italian National Forest Inventory (INFC 2005) was carried out. Moreover, a BEF calculated as the ratio of total above-ground or compartment biomass to stem volume was used to define the sensitivity of BEF to age and to tree density. Variation of aboveground standing biomass estimated with allometric equations was evaluated according to 6 differing planting densities $(833,1000,1250,1667,2000$ and 2500 trees $\mathrm{ha}^{-1}$ ). In the first 20 years after planting, higher biomass stock was detected in high density plots, but after the age of 32 years differences between plots disappeared. When the plantation was 40 years old, the highest amount of total biomass was observed in plots of 2000 trees ha $^{-1}$ (about $405 \mathrm{Mg}$

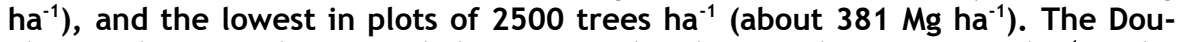
glas-fir plantation has a total above-ground carbon stock of $197 \mathrm{Mg} \mathrm{C} \mathrm{ha-1}^{-1}$ at the age of 40 and a mean annual $\mathrm{CO}_{2}$ sequestration of $18 \mathrm{Mg} \mathrm{ha}^{-1} \mathrm{y}^{-1}$. On average, constant BEF from INFC underestimated biomass by $11 \%$ at ages 15 and 25 and overestimated biomass by $16 \%$ at older ages. BEFs expressed as a ratio of biomass to stem volume significantly depended upon age and planting density, with decreasing trends for total, stem and crown compartments. Our results indicated that total above-ground biomass production is not influenced by different tree density if considered over a long period. If cutting cycles are short, planting density of 2000 trees $^{-1} \mathrm{~A}^{-1}$ may ensure high biomass production rates; for longer cutting cycles, 1000-1200 trees ha ${ }^{-1}$ could also be a valid choice.

Keywords: Allometric Equations, Biomass, Biomass Expansion Factor, Carbon, Douglas-fir, Planting Density, Spacing Trial

\section{Introduction}

Douglas-fir (Pseudotsuga menziesii (Mirb) Franco var. menziesii) is a species native to western north America which has been widely used in the reforestation of abandoned rural areas in Italy, particularly along the Apennines, because of its rapid growth and adaptability (Ciancio et al. 1982). It has been usually managed with 30-70 years cutting cycle, with harvest of total stand volume, mainly destined for use in construction.

The crucial phase of a reforestation project is the choice of tree-density and spacing, because these are parameters influencing the kind of management to adopt and the costs during the early phase after planting (Corona et al. 2002, Sanesi et al. 2007). Furthermore planting density strictly affects management, due to the ecological, silvicultural and economic implications (Ciancio et al. 1982, La Marca 1985, Menguzzato \& Tabacchi 1995,
La Marca et al. 1998, Ciancio et al. 2005). Considering the biomass distribution at tree and stand level, planting density and spacing are fundamental elements to be accounted for. In the context of global warming potential, information concerning the influence of planting density on biomass allocation is exwhich adhere to the Kyoto Protocol are requested to adopt forms of forest management which may enhance the atmospheric $\mathrm{CO}_{2}$ absorption (UNEP 1997). Currently, planting density adopted for reforestation, and for plantations destined to biomass production for energy, is generally lower compared to the past, when planting density was chosen without considering its effects on carbon stocking. The choice then revolved around the wood quality (tree grown in high density stands showed better mechanical characteristics) and traditional management as defined tremely important, because all the countries
(1) Department of Agraria, Mediterranean University of Reggio Calabria, loc. Feo di Vito, I-89060 Reggio Calabria (Italy); (2) ISAFoM, Institute for Mediterranean Agriculture and Forest Systems, CNR - National Research Council, I-87037 Rende (CS, Italy); (3) Department of Chemical and Environmental Engineering, University of Calabria, Campus di Arcavacata, I-87037 Rende (CS, Italy)

(a) Pasquale Antonio Marziliano (pasquale.marziliano@unirc.it)

Received: Jul 18, 2013 - Accepted: Jun 05, 2014

Citation: Marziliano PA, Coletta V, Menguzzato G, Nicolaci A, Pellicone G, Veltri A, 2015. Effects of planting density on the distribution of biomass in a douglas-fir plantation in southern Italy. iForest 8: 368-376 [online 2014-09-09] URL: http://www. sisef.it/iforest/contents/?id=ifor1078-007

Communicated by: Emanuele Lingua

by the German forestry school (Ciancio et al. 2008). Currently, the practice of adopting lower planting densities is more widespread for the following reasons: (i) the higher cost of young plants; (ii) the need to pass through rows with specialized machinery to carry out maintenance operations; (iii) the convenience of postponing early thinning with the aim to harvest larger trees.

In Italy high density plantations were normally established because of the costs of manpower and young plants were low. Such plantations presented high tree density even at a late stage, since no silvicultural intervention has been carried out (difficulty in trading small dimension trees). As a consequence, losses due to self-thinning, meteoric causes and pathogen attacks occurred with high frequency. In conifers, a higher density results in a lower tree diameter growth and, to a lesser extent, tree height may be lowered or suppressed (Jones 1987).

At stand level wood production increases with increasing stand density because the volume associated with the additional trees more than compensates for the decrease in the size of individuals (Dickens et al. 2004). At later ages of stands, it often happens that stands with differing densities do not result in different wood production, because the growth rate of high-density stands reaches a maximum and begins to decline earlier than lower-density stands.

In Italy spacing trials (without thinning) in Douglas-fir plantations were carried out on the coastal chain in Calabria (southern Italy Ciancio et al. 1982, Menguzzato \& Tabacchi 1995, Ciancio et al. 2008) and in Tuscany (La Marca 1985). In the USA the first trials 
were performed in 1925 (Reukema 1979). In France the first spacing trials were carried out in 1955 by Mitchell et al. (1983) and in 1971 by Bartoli (1971), whereas in Germany the first spacing trials date back to 1958 and 1961 (Kenk 1981).

Assessments of forest stand carbon dynamics, nutrient fluxes, and tree growth often include estimates of tree biomass (Devine et al. 2011). In the present study, we aim at evaluating the above-ground biomass distribution and subsequently the carbon stock of a Douglas-fir plantation in southern Italy. We consider the effects of planting density on the distribution of biomass and its partitioning to stem and crown compartments, using a spacing trial measured periodically over 25 years. Quantifying forest productivity following the guidelines by the Intergovernmental Panel on Climate Change (IPCC 2003), allows us to finally define the role of management in strengthening the global warming potential of the plantation under study. Two methods were used to estimate carbon stock (IPCC 2003): (i) allometric equations designed for the Douglas-fir plantation grown under the same conditions as the plantation in our study (Menguzzato \& Tabacchi 1995); and (ii) a constant biomass expansion factor (BEF) taken from the Italian National Forest Inventory (INFC 2005). Moreover, a BEF derived as the ratio be tween stand characteristics (Lehtonen et al 2004) was used to develop BEFs that are dependent on stand age for the whole tree, stem and crown biomass, taking into account the planting density. Considering that currently in Italy there are no spacing trials which account for biomass allocation over a long period of time, the present study aims at producing a more in-depth knowledge of biomass allocation in Douglas-fir plantations differing in planting density.

To summarize, the final aims of this study were: (i) to evaluate above-ground, stem and crown biomass of a Douglas-fir stand and its changes over time according to different planting densities; (ii) to compare different estimation methods of biomass stock of trees (allometric equations and constant BEF); (iii) to determine age dependent functions of BEFs.

\section{Material and Methods}

\section{Study site}

The study area is located in the central coastal chain of Calabria, on the western flank of the southern Apennines exposed to the Tyrrhenian sea. The locality is called Serra Salinaro $\left(39^{\circ} 25^{\prime} \mathrm{N}, 16^{\circ} 2^{\prime} \mathrm{E}\right.$, mean altitude $900 \mathrm{~m}$ a.s.1.). It is the property of the regional Italian State Forestry Agency (Azienda di Stato Foreste Demaniali ASFD) that afforested the area in 1967 mainly with Douglas-fir and to a lesser de- gree with white pine (Pinus strobus L.), black pine (Pinus nigra Arnold var. calabri$c a$ ), atlas cedar (Cedrus atlantica (Endl. Carrierre), maritime pine (Pinus pinaster Ait.), silver fir (Abies alba Mill.) and Japanese larch (Larix leptolepis (Sieb. Et Zucc.) Gard. $=$ L. Kaempferi Sarg.). The understory vegetation is mainly constituted of fern (Pteridium aquilinum (L.) Kuhn), bramble (Rubus ulmifolius Schott, 1818) and holly (Ilex aquifolium $\mathrm{L}$.). The plantation is part of a reforestation project carried out in southern Italy with funding earmarked by national government to restore forest ecosystems in abandoned agricultural land. Rapid growth non-indigenous species were largely used, with the final aim of obtaining a continuous covering of land in a short time.

Climatic data have been collected from the meteorological station of Guardia Piemontese (515 $\mathrm{m}$ a.s.l., $5 \mathrm{~km}$ apart), and climatic equations proposed by Ciancio (1971) have been used to define climatic data related to the altitude of the location under study. The climate is typically Mediterranean. The annual rainfall is $1233 \mathrm{~mm}$, with minimum precipitation in summer $(88 \mathrm{~mm})$ and a maximum during the winter $(501 \mathrm{~mm})$. Average annual temperature is $11.5^{\circ} \mathrm{C}$ at an altitude of $950 \mathrm{~m}$ a.s.l. Average temperature of the coldest month is $3{ }^{\circ} \mathrm{C}$, while the warmest has an average temperature of $20.8{ }^{\circ} \mathrm{C}$. According to Pavari's phytoclimatic classification (Pavari 1959), the plantation is located between warm and cold sub-zones of Castanetum. The problem of summer aridity is absent, owing to abundant precipitation, frequent fogs and exposure to moist air from the Tyrrhenian sea (Cantore \& Iovino 1989).

Geologically the site is underlain by green and purple Paleozoic schist. According to FAO soils classification (FAO 1998) soils are brown Podzols, with a plinthic horizon starting within $50 \mathrm{~cm}$ from the soil surface, deriving from basic metamorphic rocks, with highly decomposed organic material in more arid sites.

\section{Experimental designs and dendrometric surveys}

Six plots with different spacing trials were identified in the plantation. The planting densities were the following:

1. Planting density $A$ : 2500 trees $\mathrm{ha}^{-1}$, with spacing of $2 \mathrm{~m}$ between rows and $2 \mathrm{~m}$ between trees (PL2500);

2. Planting density $B: 2000$ trees $\mathrm{ha}^{-1}$, with spacing of $2 \mathrm{~m}$ between rows and $2.5 \mathrm{~m}$ between trees (PL2000);

3. Planting density $C: 1667$ trees $\mathrm{ha}^{-1}$, with spacing of $2 \mathrm{~m}$ between rows and $3 \mathrm{~m}$ between trees (PL1667);

4. Planting density $D: 1250$ trees ha ${ }^{-1}$, with spacing of $2 \mathrm{~m}$ between rows and $4 \mathrm{~m}$ between trees (PL1250);

5. Planting density $E$ : 1000 trees ha ${ }^{-1}$, with spacing of $2.5 \mathrm{~m}$ between rows and $4 \mathrm{~m}$ between trees (PL1000);

6. Planting density $F$ : 833 trees $\mathrm{ha}^{-1}$, with spacing of $3 \mathrm{~m}$ between rows and $4 \mathrm{~m}$ between trees (PL833);

Each plot had an area of $5000 \mathrm{~m}^{2}$. Within each plot two sub-plots of $900 \mathrm{~m}^{2}$ were earmarked for dendrometric surveys with a subsequent testing of the effects of different planting densities. In each plot (12 plots), two orthogonal diameters at breast height $(D B H)$ of all trees were measured. In addition, the total height $(\mathrm{Ht})$ of a representative sample (about 50\%) of trees was measured. Dendrometric surveys were performed over a 25 year period. Initially, when the stand was 15 years old, and then again at age 25,32 and 40 . In each plot the removal of dead trees was carried out for phytosanitary reasons. Tab. 1 shows the main dendrometric parameters for the six planting densities at the age considered.

\section{Allometric equations and biomass expansion factors}

Due to the lack of equations which allow the prediction of below-ground biomass for Douglas-fir plantation, in this study only the above-ground biomass has been considered. The biomass of each component (total above-ground, stem and crown) at tree-level was estimated from the diameter at breast height $(D B H)$ using equations by Menguzzato \& Tabacchi (1995), with different coefficients for different planting densities. Tab. 2 shows the equations used for the estimation of stem, crown and total above-ground biomass. Some statistics on sample trees collected in the six plots with differing planting densities are also reported. Equations were used to predict biomass at tree and stand level for all ages, when plantation was 15 , $25,32,40$ years old.

A conversion procedure was also adopted based on biomass expansion factors (BEFs), proposed by the Intergovernmental Panel on Climate Change (IPCC 2003) guidelines for the cases where no specific biomass models are available (Houghton et al. 1997). A constant BEF from the INFC for conifer plantations in Italy (BEF $=1.41$; basic wood density $=0.43$ ) was multiplied by aggregated stand-level volume. To estimate stem volume at tree level, volume equation for Pseudotsuga menziesii (Mirb.) Franco from the INFC (Tabacchi et al. 2011) was used.

A second BEF was developed from the data of volume and biomass at stand level per hectare as the ratio of total or component dry biomass to stem volume (Lehtonen et al. 2004 - eqn. 1):

$$
B E F=\frac{W_{i}}{V}
$$

where $W_{\mathrm{i}}$ is total or component dry biomass 
Tab. 1 - Main dendrometric parameters of stands for each planting density at the ages considered.

\begin{tabular}{|c|c|c|c|c|c|c|c|}
\hline $\begin{array}{c}\text { Planting } \\
\text { density } \\
(\text { trees ha') }\end{array}$ & $\begin{array}{c}\text { Age } \\
\text { (year) }\end{array}$ & $\begin{array}{c}\text { Current } \\
\text { density } \\
\left(\mathrm{ha}^{-1}\right)\end{array}$ & $\begin{array}{c}\text { Cumulative } \\
\text { Mortality } \\
(\%)\end{array}$ & $\begin{array}{c}\text { Basal } \\
\text { area } \\
\left(\mathbf{m}^{2} \mathbf{h a}^{-1}\right)\end{array}$ & $\begin{array}{c}\text { Quadratic } \\
\text { mean DBH } \\
(\mathrm{cm})\end{array}$ & $\begin{array}{l}\text { Stand } \\
\text { height } \\
(\mathrm{m})\end{array}$ & $\begin{array}{l}\text { Volume } \\
\left(\mathrm{m}^{3} \mathrm{ha}^{-1}\right)\end{array}$ \\
\hline \multirow[t]{4}{*}{2500} & 15 & 1989 & 20 & 36.66 & 15.3 & 12.5 & 215.8 \\
\hline & 25 & 1634 & 35 & 54.27 & 20.6 & 19.9 & 486.37 \\
\hline & 32 & 1333 & 47 & 58.46 & 23.6 & 24 & 623.35 \\
\hline & 40 & 946 & 62 & 64.44 & 29.5 & 29.4 & 830.68 \\
\hline \multirow[t]{3}{*}{2000} & 15 & 1860 & 7 & 34.75 & 15.4 & 12.2 & 200.09 \\
\hline & 32 & 1398 & 30 & 56.88 & 22.8 & 23.8 & 602.29 \\
\hline & 40 & 1280 & 36 & 62.88 & 25 & 28.6 & 792.28 \\
\hline \multirow[t]{4}{*}{1667} & 15 & 1538 & 8 & 32.89 & 16.5 & 13.1 & 201.52 \\
\hline & 25 & 1409 & 16 & 49.41 & 21.1 & 21.4 & 473.89 \\
\hline & 32 & 1151 & 31 & 54.93 & 24.7 & 25.6 & 622.34 \\
\hline & 40 & 925 & 45 & 59.97 & 28.7 & 29.8 & 783.63 \\
\hline \multirow[t]{3}{*}{1250} & 15 & 1122 & 10 & 26.83 & 17.5 & 11.9 & 150.45 \\
\hline & 32 & 900 & 28 & 54.71 & 27.8 & 23.4 & 566.79 \\
\hline & 40 & 778 & 38 & 66.26 & 32.9 & 28.2 & 818.26 \\
\hline \multirow[t]{4}{*}{1000} & 15 & 967 & 3 & 24.12 & 17.8 & 11.8 & 134.09 \\
\hline & 25 & 933 & 7 & 46.61 & 25.2 & 19.5 & 407.06 \\
\hline & 32 & 889 & 11 & 56.83 & 28.5 & 23.7 & 595.62 \\
\hline & 40 & 811 & 19 & 68.28 & 32.7 & 28.6 & 854.86 \\
\hline \multirow[t]{4}{*}{833} & 15 & 689 & 17 & 20.66 & 19.5 & 11.8 & 114.4 \\
\hline & 25 & 689 & 17 & 42.15 & 27.9 & 19 & 357.94 \\
\hline & 32 & 678 & 19 & 53.54 & 31.7 & 24.4 & 575.43 \\
\hline & 40 & 667 & 20 & 65.31 & 35.3 & 27.9 & 796.99 \\
\hline
\end{tabular}

at stand level per hectare $\left(\mathrm{Mg} \mathrm{ha}^{-1}\right)$ estimated with the allometric equation by Menguzzato \& Tabacchi (1995), $V$ is the stem volume at stand level per hectare $\left(\mathrm{m}^{3} \mathrm{ha}^{-1}\right)$, determined with the equation by Tabacchi et al. (2011). The BEF was also calculated for both crown and stem biomass.

The second BEF was used to define the age-dependent functions of BEF, in order to predict the BEFs for each biomass component depending on stand age and planting density.

\section{Data analysis}

A linear regression was used to correlate the distribution of above-ground biomass to planting density for every age. Analysis of variance (ANOVA) based on a scheme of randomized blocks (six planting density repeated twice) was carried out to test the differences in biomass stock, mean increments of biomass and partitioning to crown and stem, between differing density plots. The significance of the differences was tested by the Tukey's method.

Both the paired-sample $T$ test and the paired-sample Z-Test (Wilkoxon test) were used to compare the biomass estimates calculated by allometric equations with the biomass estimates calculated by the constant BEF from INFC. The $\mathrm{T}$ test is a parametric test known to be more statistically powerful; on the other hand, the Z-Test is non-parametric and requires almost no assumptions. Applied statistic textbooks (Zar 1996, Mont- gomery 2001, Soliani 2008) usually recommend to use both tests in order to truly verify the estimates.

For each planting density and for each biomass component, age-dependent functions of BEF were defined with a stepwise regression. A power function provided the best fit for each planting density and for every BEF component (stem, crown and total tree). We used an F-test for parallelism (mathematical similarity) to compare the null hypothesis of a unique equation for all planting densities with the alternate hypothesis of six equations with different coefficients. In all cases, the null hypothesis was rejected.

Data analysis was carried out using the statistical software R version 2.3.0 (R Development Core Team 2008).

\section{Results}

\section{Evaluation of biomass allocation and partitioning}

Tree mortality occurred in all plots during the years of survey. It was higher in high planting density stands (Tab. 1), as noticed by Menguzzato \& Tabacchi (1995) and Ciancio et al. (2008). A high mortality rate (62\% at the age of 40 years) was observed for the PL2500 plots. Plots belonging to

Tab. 2 - Equations for stem, crown and total biomass estimates, and minimum and maximum diameter values of the sampled trees (source: Menguzzato \& Tabacchi 1995, modified).

\begin{tabular}{|c|c|c|c|}
\hline $\begin{array}{l}\text { Planting density } \\
\left(\text { trees } \mathrm{ha}^{-1}\right)\end{array}$ & $\begin{array}{l}\text { Biomass } \\
\text { component }\end{array}$ & Equation & $\begin{array}{l}\text { DBH sampled trees } \\
\quad(\min -\max , \mathbf{c m})\end{array}$ \\
\hline \multirow[t]{3}{*}{ A: 2500} & Stem & $-15.85+0.33 \mathrm{dbh}^{2}$ & \multirow{3}{*}{$11.5-28.8$} \\
\hline & Crown & $-7.14+0.16 \mathrm{dbh}^{2}$ & \\
\hline & Total & $-22.76+0.49 \mathrm{dbh}^{2}$ & \\
\hline B: 2000 & Stem & $-27.94+0.40 \mathrm{dbh}^{2}$ & \multirow{3}{*}{$10.3-29.0$} \\
\hline \multirow[t]{2}{*}{ C: 1667} & Crown & $-9.74+0.17 \mathrm{dbh}^{2}$ & \\
\hline & Total & $-33.40+0.56 \mathrm{dbh}^{2}$ & \\
\hline \multirow[t]{3}{*}{ D: 1250} & Stem & $-12.79+0.31 \mathrm{dbh}^{2}$ & \multirow{3}{*}{$13.5-32.8$} \\
\hline & Crown & $-9.06+0.18 \mathrm{dbh}^{2}$ & \\
\hline & Total & $-20.45+0.48 \mathrm{dbh}^{2}$ & \\
\hline E: 1000 & Stem & $-8.82+0.30 \mathrm{dbh}^{2}$ & \multirow{3}{*}{$15.3-35.3$} \\
\hline \multirow[t]{2}{*}{ F: 833} & Crown & $0.70+0.18 \mathrm{dbh}^{2}$ & \\
\hline & Total & $-5.95+0.47 \mathrm{dbh}^{2}$ & \\
\hline
\end{tabular}


Fig. 1 - Above-ground biomass expressed in $\mathrm{Mg} \mathrm{ha}^{-1}$, of stands with different planting density, for each age considered.

Fig. 2 - Regression lines between above-ground biomass and planting density. Each dot repre-

sents the estimated above-ground biomass in each plot.

Fig. 3 - Mean values of above-ground biomass per hectare with an approximate $95 \%$ confi-

dence interval $( \pm 2$

Standard Error) at the age of 15 (a) and 40

(b).
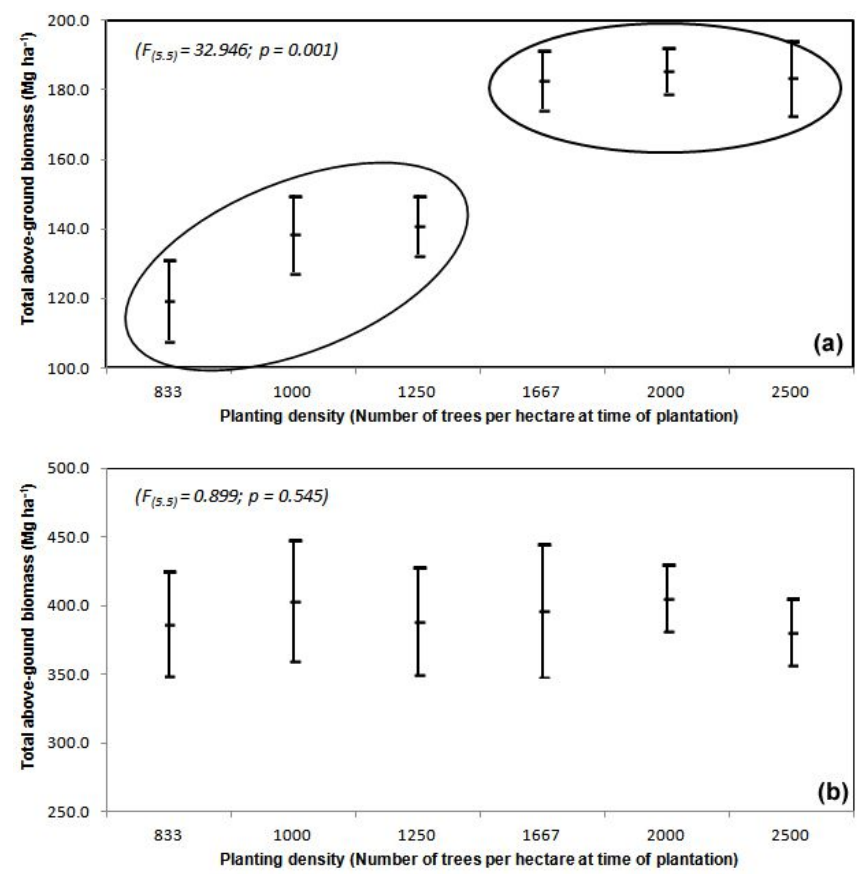

Fig. 4 - Variation of mean annual increment (MAI) of aboveground biomass with the age of stands.
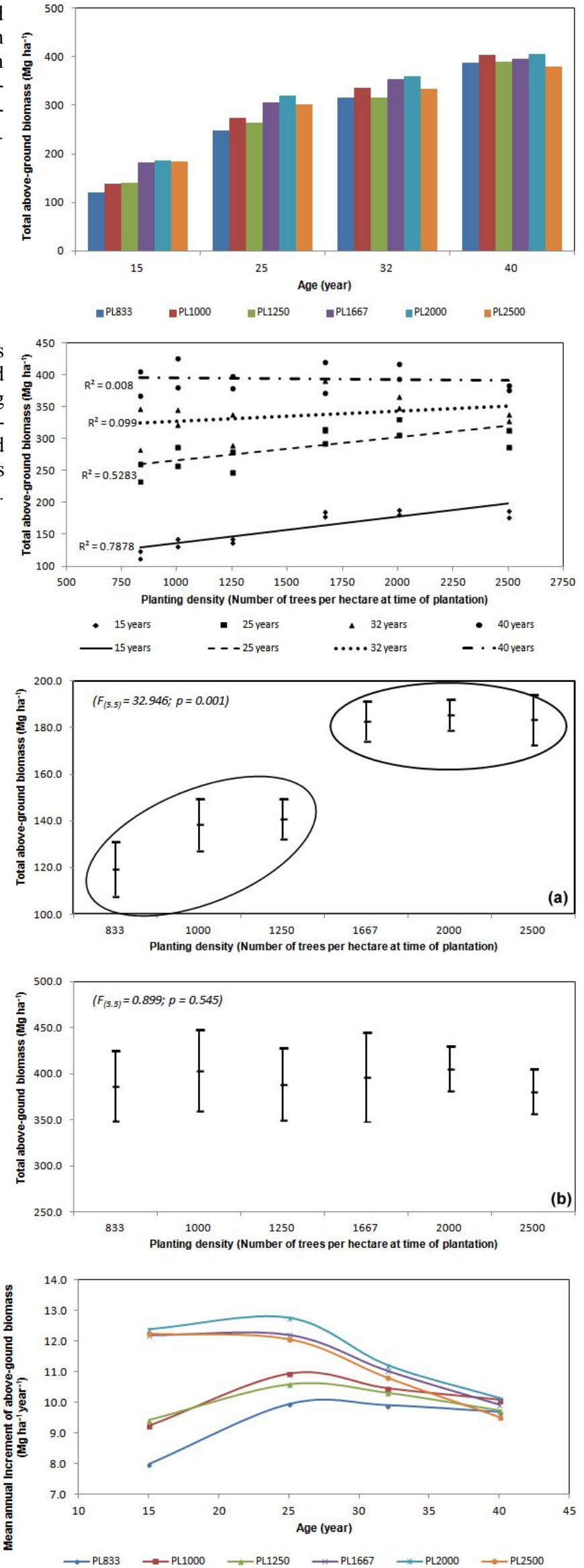

PL2000, PL1667 and PL1250 were less subject to mortality (about $40 \%$ ) and the lowest mortality rates were detected in plots of PL1000 and PL833 (about 20\%). When the plantation was 40 years old, higher current density was detected in PL2000 (1280 trees $\mathrm{ha}^{-1}$ ).

Total above-ground standing biomass at age 15 ranged from 120 to $186 \mathrm{Mg} \mathrm{ha}^{-1}$ (Fig. 1), and reached $400 \mathrm{Mg} \mathrm{ha}^{-1}$ at age 40 . At the age of 15 , total above-ground biomass per hectare increased with increasing density from 833 to 1667 trees ha ${ }^{-1}$ (Fig. 1); however, the higher biomass stock was detected in PL2000 plots rather than in PL2500 plots. At the age of 25, PL1000 plots showed higher above-ground biomass in comparison to PL1250 plots; at age 40, the plots with higher biomass stock were those in PL1000 and PL2000 (about $405 \mathrm{Mg} \mathrm{ha}^{-1}$ ), with no differences between them.

For all the stand ages total above-ground biomass was regressed against planting density (Fig. 2). At the age of $15 R^{2}$ was significant (0.788), but after 10 years ( 25 years) $R^{2}$ was lower (0.527) though still significant. At 32 and 40 years of age, $R^{2}$ was equal to 0.099 and 0.008 , respectively, thus the statistic correlation was absent.

At age 25 years above-ground biomass was dependent upon tree density, whereas at older ages the proportionality tended to disappear, and at the age of 30 it was totally absent. When the plantation was 40 years old, the highest amount of total biomass was detected in PL2000 (about $405 \mathrm{Mg} \mathrm{ha}^{-1}$ ), while the lowest was in the PL2500 plots (about $381 \mathrm{Mg} \mathrm{ha}^{-1}$ ), the other plots showing values in the range 385-404 $\mathrm{Mg} \mathrm{ha}^{-1}$.

Analysis of variance (ANOVA) was carried out to test for differences between different density plots. Significant difference was found for ages 15 (Fig. 3a) and 25. No significant difference was found for ages 32 and 40 (Fig. 3b). At age 15 two groups significantly differed, but within each group no differences were detected (Fig. 3a). The first group showed higher values of aboveground biomass (on average, $184 \mathrm{Mg} \mathrm{ha}^{-1}$ ) and was made up of plots with higher tree density (1667 and 2500 trees ha $\left.{ }^{-1}\right)$; the second group showed a mean above-ground biomass of $133 \mathrm{Mg} \mathrm{ha}^{-1}$ and was made up of plots with lower tree density (833 and 1250 trees $\mathrm{ha}^{-1}$ ). Ten years later (1992) differences between the two groups were no more significant and with increasing age, differences tended to disappear (Fig. 3a).

The mean annual increment (MAI) of total standing above-ground biomass at the age of 40 resulted high in all the plots considered (Fig. 4), reaching $9.8 \mathrm{Mg} \mathrm{ha}^{-1}$ year $^{-1}$, with no significant difference between differing planting densities. Differences were significant at ages 15 and 25 . Two groups could be distinguished: (i) the first was made up of plots 
with planting density from 833 to 1250 trees $\mathrm{ha}^{-1}$; (ii) the second was made up of plots from 1667 to 2500 trees $\mathrm{ha}^{-1}$. In the first group, at the ages of 15, 25 and 32, the mean annual increments of biomass were lower than those in the second group. Furthermore, at age 15 the differences between mean increments in plots with high planting density were null, whereas they were higher in plots with low density. The trend of mean annual increments increased in plots with planting density from 833 to 1250 trees $^{-1} \mathrm{a}^{-1}$ until the age of 25 , and then it remained constant. In plots from 1667 to 2500 trees $\mathrm{ha}^{-1}$, the mean annual increment of biomass slightly slowed down. At the age of 32, mean annual increments resulted to be similar but yet two groups could be detected. At the age of 40 differences disappeared and the culmination of mean biomass increments occurred in low density plots, whereas in higher density plots culmination had been recorded before.

With regard to carbon partitioning to the tree compartments considered, mean crown biomass ranged from 32 to $37 \%$ of total above-ground biomass at age 15 (Fig. 5), with significant differences between plots and higher percentage values detected in low density plots. In these plots the percentage of biomass allocated to the crowns was almost constant over time (slightly decreasing), with no significant differences (Tab. 3). In plots with high density the relative share of biomass in the crown compartment had a decreasing trend over time, with no significant differences in PL1667 plots and with significant differences in PL2000 and PL2500 plots (Fig. 5 and Tab. 3). At the age of 40 crown biomass ranged from 29.5 to $37 \%$ of total biomass, with highly significant differences between plots.

\section{Comparison between methods}

The main statistic parameters related to biomass values estimated with allometric equations (Menguzzato \& Tabacchi 1995) against constant BEF from inventory (INFC 2005) are shown in Tab. 4. For ages 15 and 25 above-ground biomass estimated with the constant BEF was lower than biomass estimated with allometric equations. On the other hand, for ages 32 and 40 above-ground biomass estimated with BEF was higher than biomass estimated with allometric equations.

The significance of the biomass estimation differences between the allometric function and the BEF approaches resulted high for all the ages (Tab. 5), indicating that BEF underestimated biomass on average by $11 \%$ for ages 15 and 25 and overestimated biomass on average by $15.7 \%$ for older ages. The differences in biomass estimates using the paired-sample $t$ test (T-test) and the Wilkoxon paired-sample test (Z-test) were significant for all the planting densities.

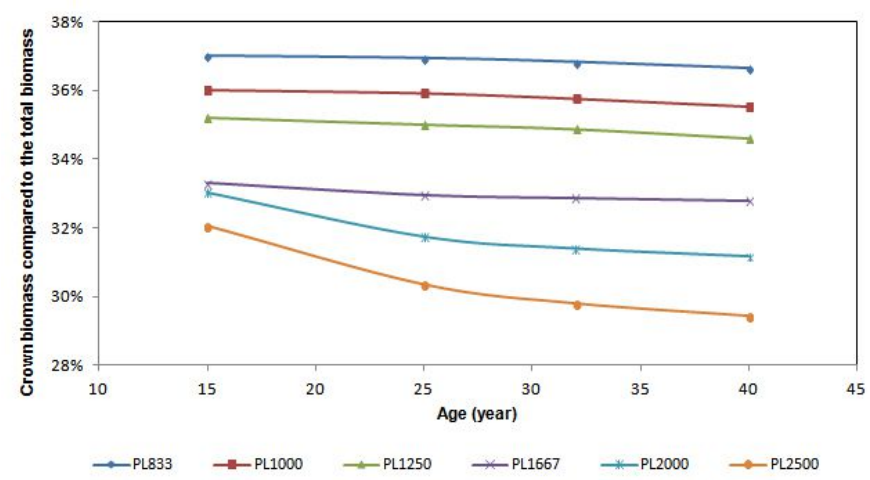

Fig. 5 - The relative contribution (\%) of crown biomass to total above-ground biomass for all the ages of stand.

Tab. 3 - Analysis of variance (ANOVA). Standing biomass by age for each planting density.

\begin{tabular}{ccccccc}
\hline $\begin{array}{c}\text { Planting } \\
\text { density }\end{array}$ & $\begin{array}{c}\text { Source of } \\
\text { variation }\end{array}$ & $\begin{array}{c}\text { Sum of } \\
\text { Squares }\end{array}$ & df & $\begin{array}{c}\text { Mean } \\
\text { Square }\end{array}$ & F & Prob. \\
\hline 833 & Age & 0.554 & 3 & 0.185 & 2.916 & 0.201 \\
& Error & 0.19 & 3 & 0.063 & & \\
\hline 1000 & Age & 0.125 & 3 & 0.042 & 0.082 & 0.966 \\
& Error & 1.53 & 3 & 0.51 & & \\
\hline 1250 & Age & 0.06 & 3 & 0.02 & 0.333 & 0.804 \\
& Error & 0.18 & 3 & 0.06 & & \\
\hline 1667 & Age & 0.18 & 3 & 0.06 & 3 & 0.196 \\
& Error & 0.06 & 3 & 0.02 & & \\
\hline 2000 & Age & 3.364 & 3 & 1.121 & 140.167 & 0.001 \\
& Error & 0.024 & 3 & 0.008 & & \\
\hline 2500 & Age & 7.214 & 3 & 2.405 & 1803.5 & $<0.001$ \\
& Error & 0.004 & 3 & 0.001 & & \\
\hline
\end{tabular}

Tab. 4 - Main statistic parameters of total above-ground biomass estimated with allometric equations $\left(W_{\mathrm{t}}\right.$ Allometric $)$ and the constant BEF from the Italian National Forest Inventory $\left(W_{\mathrm{t}} B E F\right.$ INFC).

\begin{tabular}{clccccc}
\hline $\begin{array}{c}\text { Age } \\
\text { (year) }\end{array}$ & Methods & $\mathbf{N}$ & $\begin{array}{c}\text { Mean } \\
\left(\mathbf{M g ~ h a}^{-1}\right)\end{array}$ & $\begin{array}{c}\text { Std. Dev. } \\
\left.\mathbf{( M g ~ h a}^{-1}\right)\end{array}$ & $\begin{array}{c}\text { Min } \\
\left.\text { (Mg ha }^{-1}\right)\end{array}$ & $\begin{array}{c}\text { Max } \\
\left.\text { (Mg ha }^{-1}\right)\end{array}$ \\
\hline 15 & $W_{\mathrm{t}}$ Allometric & 12 & 158.6 & 28 & 113.7 & 189 \\
& $W_{\mathrm{t}}$ BEF INFC & 12 & 136.5 & 25.4 & 96.4 & 169.4 \\
\hline 25 & $W_{\mathrm{t}}$ Allometric & 12 & 285.3 & 29.7 & 234.4 & 331.3 \\
& $W_{\mathrm{t}}$ BEF INFC & 12 & 269.8 & 33.6 & 205.5 & 318.6 \\
\hline 32 & $W_{\mathrm{t}}$ Allometric & 12 & 335.6 & 30 & 284.5 & 391.7 \\
& $W_{\mathrm{t}}$ BEF INFC & 12 & 370.4 & 31.8 & 314.3 & 421.7 \\
\hline \multirow{2}{*}{40} & $W_{\mathrm{t}}$ Allometric & 12 & 393.8 & 20 & 367.8 & 425.9 \\
& $W_{\mathrm{t}}$ BEF INFC & 12 & 504.6 & 32.1 & 446.1 & 570.2 \\
\hline
\end{tabular}

Variation of BEF according to planting density and age

The variation of stand level BEFs, calculated as the ratio between biomass and stem volume, was analyzed for all the plots and ages (Fig. 6). $\mathrm{BEFs}_{\text {total }}$ ranged from 0.442 to $0.723 \mathrm{Mg} \mathrm{m}^{-3}$ (Fig. 6a), BEFs $\mathrm{stem}_{\text {stom } 0.294}$ to $0.489 \mathrm{Mg} \mathrm{m}^{-3}$ (Fig. 6b) and $\mathrm{BEFs}_{\text {crown }}$ from

0.145 to $0.283 \mathrm{Mg} \mathrm{m}^{-3}$ (Fig. 6c). At ages 15 and $25, \mathrm{BEFs}_{\text {total }}$ showed a decreasing trend with increasing planting density, but the correlation between density and the relative BEFs was not significant. At older ages the trend completely disappeared. $\mathrm{BEFs}_{\text {stem }}$ were higher in the three plots with higher density (Fig. 6b), with significant differences be-

Tab. 5 - Significance of the biomass estimation differences between the allometric equation and the constant BEF from the Italian National Forest Inventory, assessed by the paired-sample $t$ test (T) and the Wilkoxon paired-sample test (Z).

\begin{tabular}{crrrr}
\hline Age & \multicolumn{1}{c}{ T } & Prob. & Z & Prob. \\
\hline 15 & 14.652 & $<0.001$ & -3.059 & 0.002 \\
25 & 4.412 & 0.001 & -2.824 & 0.005 \\
32 & -12.612 & $<0.001$ & -3.059 & 0.002 \\
40 & -16.674 & $<0.001$ & -3.059 & 0.002 \\
\hline
\end{tabular}




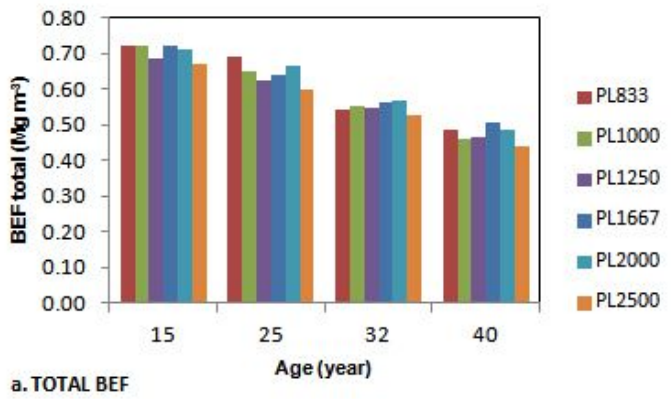

Fig. 6 - Variation of total (a), stem (b) and crown (c) BEFs with the age of stands, for each planting density.

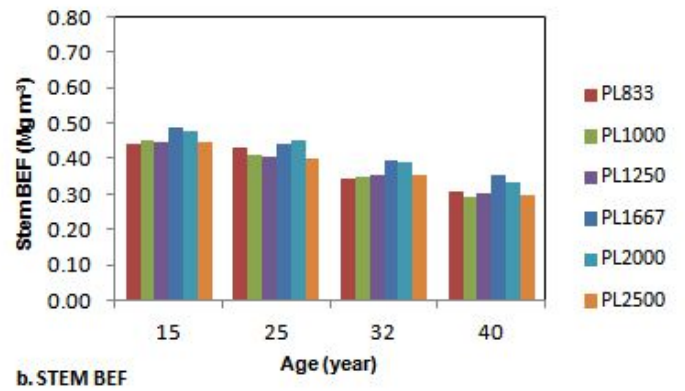

STEM BEF

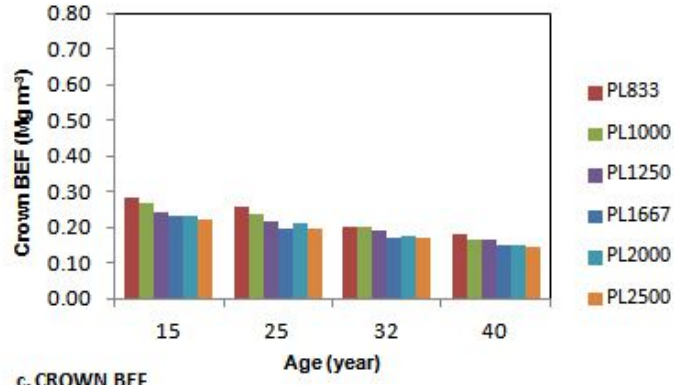

c. CROWN BEF
Fig. 7 - Age-dependent functions of crown and stem BEFs in plots with 1667 trees ha ${ }^{-1}$ at time of planting (the trend is the same for all the plots).

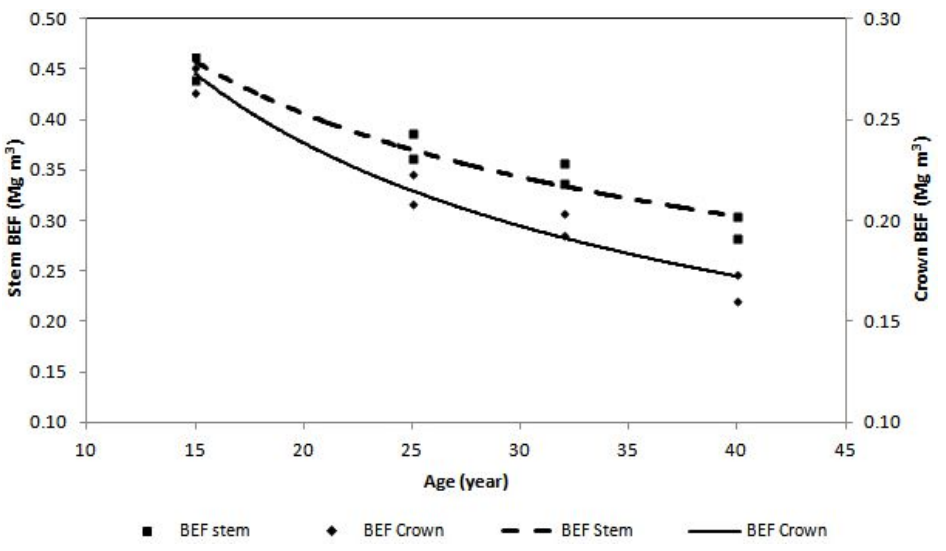

Tab. 6 - Age-dependent functions for total above-ground, crown and stem dry biomass. Equation form is $B E F_{\mathrm{i}}=a(A g e)^{\mathrm{b}}$, where $B E F_{\mathrm{i}}$ is the $B E F$ of tree component $\left(\mathrm{Mg} \mathrm{m}^{-3}\right) ; A g e$ is the independent variable (years); $a$ is the equation constant; $b$ is the equation parameter; $\mathrm{R}^{2}$ is the coefficient of determination; S.E.E. is standard error of estimation.

\begin{tabular}{lcccccr}
\hline Compartment & $\begin{array}{c}\text { Planting density } \\
\text { (Trees ha }^{-1} \text { ) }\end{array}$ & $\boldsymbol{a}$ & $\boldsymbol{b}$ & $\mathbf{R}^{\mathbf{2}}$ & S.E.E. & Prob. \\
\hline BEF total & 833 & 2.352 & -0.417 & 0.834 & 0.078 & 0.002 \\
& 1000 & 2.481 & -0.441 & 0.895 & 0.064 & $<0.001$ \\
& 1250 & 1.993 & -0.38 & 0.906 & 0.053 & $<0.001$ \\
& 1667 & 1.923 & -0.356 & 0.96 & 0.031 & $<0.001$ \\
& 2000 & 2.088 & -0.381 & 0.875 & 0.061 & $<0.001$ \\
& 2500 & 2.099 & -0.408 & 0.913 & 0.053 & $<0.001$ \\
\hline BEF crown & 833 & 1.055 & -0.47 & 0.882 & 0.072 & $<0.001$ \\
& 1000 & 1.003 & -0.47 & 0.915 & 0.061 & $<0.001$ \\
& 1250 & 0.69 & -0.375 & 0.901 & 0.052 & $<0.001$ \\
& 1667 & 0.763 & -0.436 & 0.98 & 0.026 & $<0.001$ \\
& 2000 & 0.787 & -0.433 & 0.913 & 0.056 & $<0.001$ \\
& 2500 & 0.717 & -0.419 & 0.922 & 0.051 & $<0.001$ \\
\hline BEF stem & 833 & 1.305 & -0.381 & 0.796 & 0.081 & 0.003 \\
& 1000 & 1.473 & -0.421 & 0.88 & 0.065 & $<0.001$ \\
& 1250 & 1.311 & -0.385 & 0.909 & 0.051 & $<0.001$ \\
& 1667 & 1.183 & -0.318 & 0.944 & 0.033 & $<0.001$ \\
& 2000 & 1.305 & -0.354 & 0.849 & 0.063 & $<0.001$ \\
& 2500 & 1.381 & -0.402 & 0.911 & 0.053 & $<0.001$ \\
\hline
\end{tabular}

tween the two groups. $B E F s_{\text {crown }}$ decreased with increasing density for all the ages considered. BEFs $\mathrm{s}_{\text {crown }}$ showed a larger decrease, of $49 \%$ from the age of 15 to the age of 40 , whereas total and stem BEFs decreased by $40 \%$.

Component and total BEFs for all planting density were regressed against age (Tab. 6). All the models provided a reasonable predictive power with $R^{2}$ values ranging between 0.834 (PL833 for BEFs total $_{\text {to }}$ and 0.980 (PL1667 for BEFs crown $_{\text {n }}$. Regardless of the planting density, the trend of stem and crown BEFs over time decreased with increasing age (Fig. 7).

\section{Discussion}

\section{Biomass stock}

The Douglas-fir plantation has a total above-ground carbon stock of $197 \mathrm{Mg} \mathrm{C} \mathrm{ha}^{-1}$ at the age of 40 , and a mean annual $\mathrm{CO}_{2}$ sequestration of $18 \mathrm{Mg} \mathrm{ha}^{-1} \mathrm{y}^{-1}$. Based on these estimations, we may consider the Douglas-fir plantation as a carbon sink.

Above-ground biomass was statistically correlated to planting density at young ages (up to 25 years), whereas at older ages the correlation disappeared. Therefore we infer that the total biomass production is not influenced by differing planting density over such a long period of time. Results should be interpreted in different ways if we consider the short-term and the long-term period. On a short term basis it seems that low planting densities lead to lower carbon stocks and lower carbon uptake than high planting densities. In lower density plots mean annual increments increased over time, and at the age of 40 stands with 833-1250 trees per hectare still produced high mean increments of 
biomass, while stands with higher tree density had already showed lower mean annual increments nearly five years earlier. Nevertheless, plots with 2000 trees $\mathrm{ha}^{-1}$, both at young and old ages, showed higher stand volume mean annual increments and higher biomass stock, along with 1000 trees $\mathrm{ha}^{-1}$ plots.

Studies on the growth of spruce stands of different initial density (e.g., McClain et al 1994) report that the denser is the stand, the more intensive is self-thinning and differentiation of trees, and that the volume and its maximum increment with age is observed in thinner stands, since the denser is the stand, the earlier this culmination occurs. This is evident in plots with 2500 trees ha ${ }^{-1}$ analyzed in the present study, where at age 40 a mortality of $62 \%$ and a stand volume of $831 \mathrm{~m}$ ha $^{-1}$ were detected, against plots with 1000 trees $\mathrm{ha}^{-1}$ where mortality at age 40 was recorded as $19 \%$ and stand volume resulted to be $855 \mathrm{~m}^{3} \mathrm{ha}^{-1}$ (Tab. 1).

In the context of carbon stocking if the harvest is planned when the stand is $15-25$ years old, high density plots can ensure high carbon stock in the short space of time considered, although this means that wood quality would be poorer. Such young plantations with high tree-density, over few years, both in rural and urban areas, greatly contribute to the creation of many environmental benefits like $\mathrm{CO}_{2}$ sequestration (McPherson \& Simpson 2000) and the mitigation of air pollution (Escobedo \& Nowak 2009, Marziliano et al 2013). Regardless the length of cutting cycles, planting density could be on average 2000 trees per hectare in order to ensure high biomass production rates, more $\mathrm{CO}_{2} \mathrm{se}-$ questration and trees with good bio-mechanical characteristics, less susceptible to snow damages and rooting out. If cutting cycles are longer, 1000-1200 trees per hectare could also be a valid choice. Trees would be well formed and stable, with good wood quality (Ciancio et al. 2008) and carbon stock would not be influenced by planting density.

\section{Biomass partitioning}

According to the hierarchy priority theory of biomass partitioning, stem growth has a lower priority than foliage and fine roo (Waring \& Schlesinger 1985, Oliver \& Larson 1996). Stand density is a factor that has a significant influence on stand carbon allocation, since it is known to affect tree crown morphology, which in turn influences the carbon allocation among stems, foliage, and branches (Dicus \& Dean 1998). These relations are complex because both stand structure and productivity are associated with differences in age and site quality (Assmann 1970, Marziliano et al. 2012). As planting density increases, both aboveground and belowground intraspecific competition increa- ses, potentially changing partitioning priorities (Burkes et al. 2003), slowing individual tree DBH growth, leading to the live crown receding, which becomes smaller in relation to the stem volume. Light penetration, height growth, crown lifting, and inter-crown abrasion simultaneously influence the canopy structure (Dean \& Long 1992). Canopy size (leaf biomass or leaf area) drives both radiation interception and photosynthetic surface area. Owing to more horizontal space availability in low density plots, trees develop wide crowns, partitioning a larger proportion of biomass into branch support because branches are longer, and more foliage is located further from the stem (Ford 1985). Crown growth rates are further enhanced by a long growing season, favorable temperature regime and soil moisture conditions, and a lack of disease and insect problems. In low planting density plots biomass allocated to crown represents an important component of above-ground biomass for all the ages of the stand. In plots of 1000 trees ha ${ }^{-1}$, at age 40 the above-ground biomass stock is the same that in plots of 2000 trees ha ${ }^{-1}$, although the crown compartment in the latter contributes only to $31 \%$ of total biomass, whereas in 1000 trees $^{-1} \mathrm{~h}^{-1}$ plots it contributes to nearly $37 \%$. In high planting density plots, after the onset of competition at crown closure, biomass allocated to crown decreases, since foliage is driven to the top of the canopy as a result of the natural pruning of lower branches (Moller 1947). Both the crown midpoint and the stem increase their height so that more carbon is needed to be allocated to stem to transport the same amount of water to the foliage, increasing the carbon sink strength of the stem (Dean 1991). Even if the individual stems allocate more carbon, the loss due to self-thinning reduces this carbon sink potential so that, at older ages of plantations, differences in stem biomass increments between denser and sparser stands are no more significant.

\section{Age-dependent BEFs}

The quantification, reporting and verification of carbon sequestered by forests are frequently not as transparent as it should be, and this has major implications on policy decisions regarding forest conservation and management (Clark et al. 2001). Availing of the allometric equations built for the area under study is a big challenge for improving our knowledge of the carbon cycle in forest ecosystems. When no site/species or forest type specific allometric models are available, it is also possible to use biomass expansion factors, even if conversion from stem volumes into whole-tree biomass is one of the notable sources of error in forest carbon inventories (Schoene 2002). The aboveground biomass of forests is often estimated with constant BEFs based either on national stu- dies or IPCC defaults (IPCC 2003), although it is well known that the relative proportions of canopy and stem in the total mass vary over the stand development (Satoo \& Madgwick 1982). According to IPCC (2003), the uncertainty involved in using generic BEF is approximately $30 \%$, but few authors found errors up to $70 \%$ (Ravindranath \& Ostwald 2008). Because trees demonstrate different biomass allocation patterns and adaptive strategies in response to abiotic factors such as temperature, water and nutrients, BEFs are hypothesized to vary with forest types and abiotic factors, although such variation has not been well examined to date (Vande Walle et al. 2005). Major changes in silvicultural practices that might lead to changes in tree allometry, affecting diameter distributions and stocking density of the stands, could also influence BEF values. The results of this study showed that BEFs expressed as ratio of biomass to volume varied with age and with planting density at the same age, confirming that the adoption of constant $\mathrm{BEFs}$ is limiting and misleading. BEFs determined in this study differed from BEFs published for Douglas-fir by other authors. Levy et al. (2004) report a mean value of above-ground BEF of 1.38 , which is higher than that found in this study. However, no specific works on BEF have been carried out so far for Mediterranean Douglas-fir plantations or in similar conditions, so a comparison is unfeasible.

Variation of BEF also occurred in the compartment level. In all plots stem, crown and total above-ground BEFs decreased over years, but they resulted different between differing planting density plots. $\mathrm{BEFS}_{\text {crown }}$ had higher values in thinner plots, whereas $\mathrm{BEFs}_{\text {stem }}$ were higher in denser stands. As reported by other authors (Correia et al. 2010) $\mathrm{BEF}_{\text {crown }}$ decreased with increasing density, and $\mathrm{BEFS}_{\text {stem }}$ increased with increasing density. Generally, BEF values are high at low stand growing stem volumes or biomass, and decrease to a constant BEF at a high stand growing stem biomass. The size-dependent pattern in BEF is generally expected to be similar to what happens for basic wood density. Such patterns have been reported by Lehtonen et al. (2004) and Kauppi et al. (1995). These results can be explained by the fact that trees grown in low-density stands usually contain relatively more biomass in branches and foliage than trees grown in high-density stands. When canopies become closed, the stems continue to accumulate dry matter, but as new branches and foliage are grown the oldest die and fall off (Kauppi et al. 1995). The decline in BEF may be associated with changes in biomass allocation in younger stands, such as a greater increment in stem wood, relative to nonwoody biomass.

The differences in the variation of $\mathrm{BEFs}_{\text {stem }}$ 
between differing planting densities can be also accounted for by the influence of stand density on wood basal density and tree rings width. The difference in wood density and its radial trends reflect growth strategy and biomechanical considerations. Such variations in wood basal density are not considered when constant BEFs from inventory are applied, but it varies among tree compartments and it largely depends both on density and on environmental conditions. Somogyi et al. (2007) suggest adopting various correction factors to use the density of the appropriate components of tree to convert volume to biomass.

When selecting or developing BEF values, care should be taken that they are representative of the forest population to which they will be applied, with respect to the species and according to tree size. The relative share of biomass components (e.g., foliage and branches) varies during stand development, according to age (Lehtonen et al. 2004), fertility (Wirth et al. 2004) and stand density (Correia et al. 2010).

\section{Conclusion}

It is fundamental to assess the carbon stock in these Mediterranean exotic species plantations whose original purpose was to ensure a prompt forest cover on abandoned land. Over the years they also provided high carbon uptake and protection from hydrogeological risks. The results of this study may be helpful for devising forest management strategies. Regardless of economic considerations, when the priority is to ensure high carbon stock, the planting density becomes a primary issue only if cutting cycles are very short.

The variability of BEF with age found in this study demonstrates that the use of constant BEF from national inventories can be misleading. Diameter distributions, age and stocking density of the stand affect the variation of BEFs. Therefore, the use of the conversion factors from national inventories, often based on relatively few sites sampled in various ecosystem studies, may lead to biased estimates of forest carbon stocks. As a consequence, the age-dependent BEF equations presented here are applicable to stands with similar diameter distribution and tree allometry, i.e., they could be applied to Douglas-fir forests aged between 15 and 40, with differing tree-density and spacing and with an average stock of biomass of $400 \mathrm{Mg} \mathrm{ha}^{-1}$.

\section{References}

Assmann E (1970). The principles of forest yield study. Studies in the organic production, structure, increment and yield of forest stands. Pergamon Press, Oxford, UK, pp. 506

Bartoli M (1971). Premier résultats (a 11 et 15 ans) d'une expérience de densité sur le Douglas [First results (ages 11 and 15) of a density expe- rience on Douglas-fir]. Revue Forestière Française 23 (6): 605-608. [in French] - doi: 10.426 $7 / 2042 / 20535$

Burkes EC, Will RE, Barron-Gafford GA, Teskey RO, Shiver B (2003). Biomass partitioning and growth efficiency of intensively managed Pinus taeda and Pinus elliottii stands of different planting densities. Forest Science 49 (2): 224-234. [online] URL: http:/www.ingentaconnect.com/ content/saf/fs/2003/00000049/00000002/art0000 6

Cantore V, Iovino F (1989). Effetti dei diradamenti sull'umidità del suolo in popolamenti di douglasia della Catena Costiera (Calabria) [Effects of thinning on soil water content in Douglas-fir stands in the Coastal Chain (Calabria)]. Annali dell'Istituto Sperimentale per la Selvicoltura 20: 13-39. [in Italian]

Ciancio O (1971). Sul clima e sulla distribuzione altimetrica della vegetazione forestale in Calabria [Climate and altimetric distribution of forest vegetation in Calabria]. Annali dell'Istituto Sperimentale per la Selvicoltura Arezzo 2: 321 370. [in Italian]

Ciancio O, Mercurio R, Nocentini S (1982). Le specie forestali esotiche nella selvicoltura italiana [Exotic forest species in the Italian silviculture]. Annali dell'Istituto Sperimentale per la Selvicoltura Arezzo 12/13: 731. [in Italian]

Ciancio O, Garfî V, Menguzzato G (2005). Effetti della densità di impianto sulla produzione in piantagioni di douglasia [Effects of planting density on productivity of Douglas fir plantations]. In: Proceedings of the IV SISEF Congress "Meridiani Foreste" (Caivano F, Girardi T, Pierangeli D, Borghetti M eds). Rifreddo (PZ, Italy) 7-10 Oct 2003. SISEF, Potenza, Italy, pp. 87-93. [in Italian]

Ciancio O, Garfì V, Marziliano PA, Menguzzato G, Pelle L (2008). Effetti della densità di impianto in popolamenti di douglasia [Effects of planting densitiy on douglas fir stands]. L'Italia Forestale e Montana 59 (6): 519-534. [in Italian with English Absract] - doi: 10.4129/IFM.2008.6.05

Clark DA, Brown S, Kicklighter DW, Chambers JQ, Thomlinson JR, NI J (2001). Measuring net primary production in forests: concepts and field methods. Ecological Applications 11: 356-370. doi: 10.1890/1051-0761(2001)011[0356:MNPP IF]2.0.CO;2

Corona P, Marziliano PA, Scotti R (2002). Topdown growth modelling: a prototype for poplar plantations in Italy. Forest Ecology and Management 161: 65-73. - doi: 10.1016/S0378-1127(01) 00481-9

Correia AC, Tomé M, Pacheco CA, Faias S, Dias AC, Freire J, Carvalho PO, Pereira JS (2010). Biomass allometry and carbon factors for a Mediterranean pine (Pinus pinea L,) in Portugal. Forest Systems 19 (3): 418-433. - doi: 10.5424/ fs/2010193-9082

Dean TJ, Long JN (1992). Influence of leaf area and canopy on size-density relations in evenaged lodgepole pine stands. Forest Ecology and Management 49: 109-117. - doi: 10.1016/03781127(92)90164-5
Dean TJ (1991). Effect of growth rate and wind sway on the relation between mechanical and water-flow properties in slash pine seedlings. Canadian Journal of Forest Research 21 (10): 1501-1506. - doi: 10.1139/x91-210

Devine WD, Harrington TB, Terry TA, Harrison RB, Slesak RA, Peter DH, Harrington CA, Shilling CJ, Schoenholtz SH (2011). Five year vegetation control effects on aboveground biomass and nitrogen content and allocation in Douglas-fir plantations on three contrasting sites. Forest Ecology and Management 262: $2187-$ 2198. - doi: 10.1016/j.foreco.2011.08.010

Dickens ED, Barnett JP, Hubbard WG, Jokela EJ (2004). Slash pine: still growing and growing! Gen. Tech. Rep. SRS-76, USDA Forest Service, Southern Research Station, Asheville, NC, USA, pp. 148.

Dicus CA, Dean TJ (1998). Stand density effects on biomass allocation patterns and subsequent soil nitrogen demand. In: Proceedings of the " $9^{\text {th }}$ Biennial Southern Silvicultural Research Conference" (Waldrop TA ed). Clemson (SC, USA) 25-27 Feb 1997. Gen. Tech. Report SRS-20, Southern Research Station, USDA Forest Service, Ashevill, NC, USA, pp. 564-568.

Escobedo FJ, Nowak DJ (2009). Spatial heterogeneity and air pollution removal by an urban forest. Landscape and Urban Planning 90: 102110. - doi: 10.1016/j.landurbplan.2008.10.021 FAO (1998). World reference base for soil resources. The latest WRB classification manual. Food and Agriculture Organization of the United Nations, Rome, Italy, pp. 128.

Ford ED (1985). Branching. crown structure and control of timber production. In: "Attributes of trees as crop plants" (Cannell MGR, Jackson JE eds). Institute of Terrestrial Ecology, Abbots Ripton, UK, pp. 228-252.

Houghton JT, Meira Filho LG, Lim B, Treanton K, Mamaty I, Bonduki Y, Griggs DJ, Callander BA (1997). Revised 1996 guidelines for national greenhouse gas inventories. IPCC/OECD/IEA, Paris, France.

INFC (2005). Linee generali del progetto per il secondo inventario forestale nazionale italiano [General guidelines of the project for the second national italian forest inventory]. In: "Inventario Nazionale delle Foreste e dei serbatoi forestali di Carbonio" (De Natale F, Floris A, Gasparini P, Scrinzi G, Tabacchi G, Tosi V eds). MiPAF - Ispettorato Generale del Corpo Forestale dello Stato, ISAFA, Trento, Italy, pp. 57. [in Italian] IPCC (2003). Good practice guidelines for land use, land-use change and forestry. Intergovernmental Panel on Climate Change, Institute for Global Environmental Strategies (IGES) for the IPCC, Hayama, Japan, pp. 599. [online] URL: http://www.ipcc-nggip.iges.or.jp/public/gpgluluc f/gpglulucf.html

Jones EP (1987). Slash pine plantation study - age 30. In: Proceedings of the " 4 th Biennial Southern Silviculture Conference" (Phyllips JR ed). Atlanta (GA, USA) 4-6 Nov 1986. Gen. Tech. Rep. SE-42, Southeastern Forest Experiment Station, USDA Forest Service, Asheville, NC, USA, pp. 
45-49.

Kauppi PE, Tomppo E, Ferm A (1995). C and N storage in living trees within Finland since 1950s. Plant and Soil 168-169 (1): 633-638. doi: 10.1007/BF00029377

Kenk G (1981). Auswirkungen von DouglasienPflanzverbanden auf Aststarken und Vernutzung sowie Uberlegungen zur Astungshohe [Impacts of planting density in a Douglas-fir plantation on the branches basal diameter and insertion height]. Allg Forst und Jagdzeitung 152 (8/9): 168-180. [in German]

La Marca O (1985). Preliminary results on spacing of trees in some Douglas-fir plantations in Italy. In: Proceedings of the IUFRO Project Group P4.02.02 Meeting "The influence of spacing and selectivity in thinning on stand development. Operations and economy" (Gallagher G ed). Dublin (Ireland) 24-28 Sep 1984. IUFRO, Vienna, Austria, pp 169.

La Marca O, Marziliano PA, Moretti N (1998) Experimental research in ageing holm oak (Quercus ilex L.) coppices: preliminary results. Annales des Sciences Forestières 55: 461-476. doi: 10.1051/forest:19980406

Lehtonen A, Mäkipää R, Heikkinen J, Sievänen R, Liski J (2004). Biomass expansion factors (BEF) for Scots pine. Norway spruce and birch according to stand age for boreal forests. Forest Ecology and Management 188: 211-224. - doi: 10.1016/j.foreco.2003.07.008

Levy PE, Hale SE, Nicoll BC (2004). Biomass expansion factors and root:shoot ratios for coniferous tree species in Great Britain. Forestry 77 421-430. - doi: 10.1093/forestry/77.5.421

Marziliano PA, Menguzzato G, Scuderi A, Corona P (2012). Simplified methods to inventory the current annual increment of forest standing volume. iForest 5: 276-282. - doi: 10.3832/ifor063 5-005

Marziliano PA, Lafortezza R, Colangelo G, Davies C, Sanesi G (2013). Structural diversity and height growth models in urban forest plantations: A case-study in northern Italy. Urban Forestry and Urban Greening 12 (2): 246-254. - doi: 10.1016/j.ufug.2013.01.006

McClain KM, Morris DM, Hills SC, Buse LJ (1994). The effects of initial spacing on growth and crown development for planted northern conifers: 37-year results. The Forestry Chronicle 70 (2): 174-182. - doi: 10.5558/tfc70174-2

McPherson EG, Simpson JR (2000). Carbon dioxide reductions through urban forestry: guidelines for professional and volunteer tree planters. Report no. PSW GTR-171, Pacific Southwest Research Station, USDA Forest Service, Albany, CA, USA, pp. 237.

Menguzzato G, Tabacchi G (1995). Prove sperimentali sulle distanze d'impianto in piantagioni di douglasia sulla Catena Costiera (Calabria) [Experimental trials on planting densities in Douglas fir plantations on the Coastal Chain (Calabria)]. L'Italia Forestale e Montana 50 (2): 170-189. [in Italian]

Mitchell KJ, Oswald H, Ottorini JM (1983). Modelling the growth of Douglas-fir in France. Mitteilungen der Forstlichen Bundesversuchsanstalt Wien 147:25-39.

Moller CM (1947). The effect of thinning, age, and site on foliage, increment, and loss of dry matter. Journal of Forestry 45: 393-404.

Montgomery D (2001). Introduction to statistical quality control $\left(4^{\text {th }}\right.$ edn). John Wiley \& Sons, New York, USA, pp. 795.

Oliver CD, Larson BC (1996). Forest stand dynamics (update edn). John Wiley and Sons, New York, USA, pp. 467

Pavari A (1959). Le classificazioni fitoclimatiche ed i caratteri della stazione [Phytoclimatic classifications and station characteristics]. Scritti di ecologia selvicoltura e botanica forestale, pp. 45116. [in Italian]

R Development Core Team (2008). R: a language and environment for statistical computing. $\mathrm{R}$ Foundation for Statistical Computing, Vienna, Austria. [online] URL: http://www.R-ptoject.org Ravindranath NH, Ostwald M (2008). Carbon inventory methods. Handbook for greenhouse gas inventory, carbon mitigation and roundwood production projects. Advances in Global Change Research 29, Springer, Heidelberg, Germany, pp. 304.

Reukema DL (1979). Fifty-year development of Douglas-fir stands planted at various spacings. Research Paper PNW-253, Pacific Northwest Forest and Range Experiment Station, USDA Forest Service, Portland, OR, USA, pp. 21. Sanesi G, Lafortezza R, Marziliano PA, Ragazzi
A, Mariani L (2007). Assessing the current status of urban forest resources in the context of "Parco Nord", Milan, Italy. Landscape and Ecological Engineering 3: 187-198. - doi: 10.1007/s11355007-0031-2

Satoo T, Madgwick HAI (1982). Forest biomass. Martinus Nijhoff/Junk, The Hague, London, pp. 152

Schoene D (2002). Terminology in assessing and reporting forest carbon change. In: "Second expert meeting on harmonizing forest-related definitions for use by various stakeholders". FAO, Rome, Italy, pp. 8.

Soliani L (2008). Statistica applicata [Applied statistics]. UNI.NOVA, Parma, Italy, pp. 694.

Somogyi Z, Cienciala E, Mäkipää R, Muukkonen P, Lehtonen A, Weiss P (2007). Indirect methods of large-scale forest biomass estimation. European Journal of Forest Research 126 (2): 197 207. - doi: 10.1007/s10342-006-0125-7

Tabacchi G, Di Cosmo L, Gasparini P (2011). Aboveground tree volume and phytomass prediction equations for forest species in Italy. European Journal of Forest Research 130 (6): 911934. - doi: 10.1007/s10342-011-0481-9

UNEP (1997). Kyoto protocol to the United Nations framework convention on climate change. United Nations Environmental Program, Kyoto, Japan, pp. 20.

Vande Walle I, Van Camp N, Perrin D, Lemeur R, Verheyen K, Van Wesemael B, Laitat E (2005). Growing stock-based assessment of the carbon stock in the Belgian forest biomass. Annals of Forest Science 62 (8): 853-864. - doi: 10.1051/ forest:2005076

Waring RH, Schlesinger WH (1985). Forest ecosystems: concepts and management. Academic Press, Orlando, FL, USA, pp. 340.

Wirth C, Schumacher J, Schulze ED (2004). Generic biomass functions for Norway spruce in central Europe - a meta-analysis approach toward prediction and uncertainty estimation. Tree Physiology 24: 121-139. - doi: 10.1093/treephys/ 24.2.121

Zar JH (1996). Biostatistical analysis ( ${ }^{\text {rd }}$ edn). Prentice Hall Inc., Englewood Cliffs, NJ, USA, pp. 718 . 